Case Study

\title{
Flash Flooding and Green Stormwater Infrastructure in Philadelphia: Areas for Further Improvement
}

\author{
Ela DOĞANAY ${ }^{1}$, Jamie MAGAZINER ${ }^{2}$ \\ ${ }^{1}$ Ministry of Forestry and Water Affairs General Directorate of Water Management 06510, Yenimahalle-Ankara - Turkey \\ eladoganay@ormansu.gov.tr \\ ${ }^{2}$ Montgomery County's Planning Commission, Norristown, PA, USA \\ jamie.magaziner@gmail.com
}

Received date: 03.05.2017, Revised date: 11.07.2017 Accepted date: 17.07.2017

\begin{abstract}
Flash flooding is one of the most dangerous and the most common catastrophes among the other types of floods occure in USA. Flash flooding may occur in any area that may not even be located in floodplain zone. Since the flash flooding can take a few minutes or a few hours without any warning and has high damaging potential, in this study, it is focused on identifying areas prone to flash flooding in the Philadelphia city, which has many natural streams and high development rates. In this study therefore, an analytical model based on Geographic Information System (GIS) was developed to find the most flash flood prone areas in Philadelphia city and determine the relationship between the combined sewer area and the locations of green stormwater infrastructure projects.
\end{abstract}

Keywords: flood, flash flood, stormwater management, Philadelphia

Öz

Ani taşkınlar, Amerika Birleşik Devletleri’nde yaşanan taşkın çeşitleri arasında en tehlikeli ve en yaygın doğal afetlerden bir tanesidir. Ani taşkınlar, taşkın riski taşımayan bölgelerde dahi, aşırı yağmur suyunun, doygunluğa ulaşmış toprak üstünde birikip yayılması ile, hiçbir uyarı vermeksizin bir kaç saat içerisinde meydana gelebilir. Bu çalışmada, bir çok nehire sahip ve yoğun kentleşmeye maruz kalan Filedalfiya şehrinde ani taşkın risk potansiyeli olan bölgeler belirlenmeye çalışılmıştır. Bu amaç doğrultusunda, Filedelfiya'daki ani taşkın riski olan bölgeleri belirlemek amacıyla Coğrafik Bilgi Sistemi (CBS)'ne dayalı analitik bir model oluşturulmuştur. Analiz sonucunda riskli olduğu belirlenen bölgelerde mevcut bulunan kanalizasyon şebekelerinin konumu ve bu bölgelerde çevreci yağmursuyu toplama yapılarının olup olmadığı ve bu sistemlerin birbiriyle olan etkileşimleri incelenmiştir.

Anahtar sözcükler: taşkın, ani taşkınlar, yă̆mur suyu kontrolü, Filedelfiya

\section{Introduction}

Philadelphia is at the forefront of using green stormwater infrastructure to mitigate flooding and stormwater issues. Philadelphia, just like many other cities those have old part in the USA, has combined sewer systems (CSS). In dry periods, sewage and stormwater do not interact, but in moderate to large rain events, sewage and stormwater combine and flow together into river systems. This is referred to a combined sewage overflow (CSO) and violates the EPA's Clean Water Act (CWA). It is because of this that Philadelphia, along with several other cities, is under mandate to decrease the number of CSOs those occur often (PWD, 2014). On the other hand, it is well known that CSOs negatively influence river ecosystems, aquatic wildlife, and water quality. They also incur more cost as a higher quantity of water sent to treatment plants. Philadelphia's long-term CSO control plan is the Green City ("with" or "together with") Clean Waters program. Due to the above reasons, Philadelphia should be strategic in its placement of green stormwater infrastructure. This project looks at the relationship between flash flooding and Philadelphia's combined sewer system. Furthermore, 
it intends to look at the potential impacts of flash flooding on combined sewer overflows.

\section{Objective}

The purpose of this analysis is to find the areas in which green stormwater projects are missing within and around Philadelphia's combined sewer area based on areas which has high flash flooding probability. The analysis is based on reclassification and weighted overlay tools for areas at highest flash flood risk. Projects will be recommended within the combined sewer area if projects are missing in the vulnerable areas defined by our analysis. The locations within both the analysis result and combined sewer area will be subjected to recommendation for further stormwater management tools.

\section{Background}

Flooding is one of the most dangerous catastrophes and the most common natural hazard in the United States. A flood can impact a local area, an entire community, or large metropolitan region, whether or not it is located within the floodplain boundary (Carlin, 2009). There are different types of flooding. Some of them develop slowly, over a period of days, while others such as flash floods, can develop intensely; in just a few minutes with little warning. Flash flooding may occur due to an accumulation of rainwater on saturated ground and the water has nowhere else to go in an area that may not even be located in floodplain zone. Increasing urbanization is one of the reasons for increasing flood risk in the areas around urban streams and rivers (Bartosova et al., 2000). This is largely due to the high density of impervious cover. Since flash flooding occures oftenly in a few minutes or hours and has high damaging potential, in this study, it was focused on identifying prone areas has flash flooding probability in the Philadelphia city, which has many natural streams and high development level.

As mentioned above, Philadelphia has approached the issue of combined sewer overflows with its long term control plan of Green City - Clean Waters program. The policies within this plan only effects the future development and runoff problems and seek to reduce the risk of pollution any further, rather than requiring mitigation for past development. At the end of the 25-year program, $\$ 2.4$ billion will have been invested by the PWD into stormwater management (PWD, 2011). In 2009, the EPA created the Urban Waters Initiative with the goals of: improving water quality to a level that makes rivers fishable/swimmable/drinkable, improving public health, the environment and quality of life, and sustaining community improvements over multiple generations (PWD, 2011). The Green Cities, Clean Waters program followed in the footsteps of this initiative and states in its report that it will keep these goals in mind in its long-term plan.

The city of Philadelphia has made great strides in mitigating the stormwater issues faced by the city in its innovative LTCP. Other cities, such as Cleveland and Washington DC, who are also under mandate by the EPA, have designed stormwater programs with a focus on 'grey infrastructure'. Grey infrastructure is the underground matrix of drainage and pipes that swiftly removes wastewater from the surface (EPA, 2013). Particularly in older cities, this infrastructure is in decline and is very costly to repair. Philadelphia's Green City - Clean Waters program is focused on green 
infrastructure, which is a general term for more 'environmentally friendly' stormwater management techniques (EPA, 2013). Other green infrastructure tools include: 1) stormwater tree trenches, 2) green roofs, 3) rain barrels, 4) pervious surfaces/paving, 5) stormwater wetlands, 6) lanters, 7) bump-outs, and 8) rain gardens (PWD, 2014). The plan also includes pipe laying and sewer reconstruction. The program is a part of the Mayor Nutter's Greenworks plan toward making Philadelphia "The Greenest City in America" (PWD, 2011).

The following map (Figure 1) shows the boundaries of Philadelphia, its combined sewer system, surface streams, and green stormwater infrastructure projects.

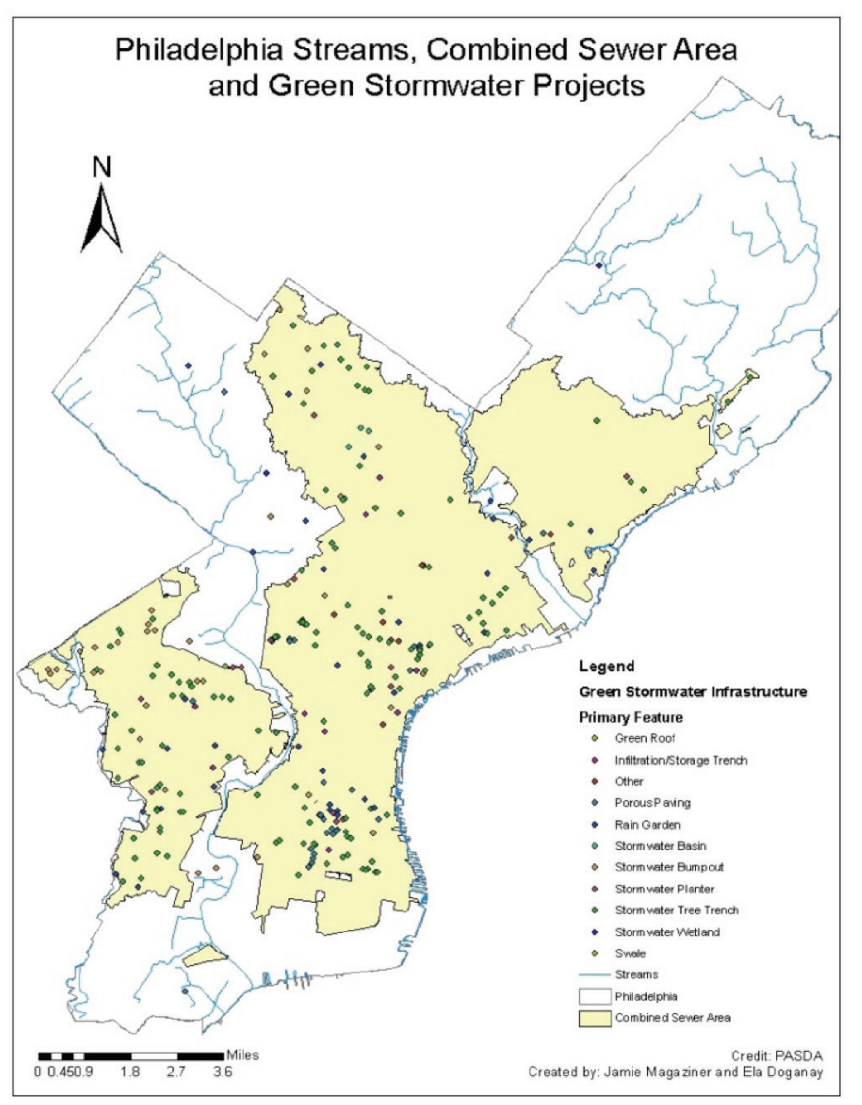

Figure 1. The boundaries of Philadelphia, its combined sewer system, surface streams, and green stormwater infrastructure projects

\section{Scope}

The purpose of this analysis is to find the areas in which green stormwater projects are missing within and around Philadelphia's combined sewer area has high probability of flash flooding. The analysis is based on reclassification and weighted overlay tools for areas at highest flash flood risk. Projects will be recommended within the combined sewer area if projects are missing in the vulnerable areas defined in this study. The locations within both the analysis result and combined sewer area will be subjected to recommendation for further stormwater management tools. This research seeks to answer several questions listed below: 
- What areas of Philadelphia are susceptible to flash flooding?

- Are these areas at inside or outside of the combined sewer area?

- Are green stormwater infrastructure projects present in these areas?

The answers to these questions and their analysis can be found in the Analysis and Results section of this paper.

\section{Literature Review and Case Studies}

The literature reviewed in this paper includes works regarding green stormwater management and its success in US cities as well as GIS projects which used the similar analysis and methodology to this work. Use of a combination of these literature types helps to this project to have a strengthened and clarified focus.

The use of green infrastructure in stormwater management plans has been growing rapidly in recent years. Keeley et al (2012) defines green infrastructure as a term "referring to the management of landscapes in ways that generate human and ecosystem benefits". Warren et al (2009) provides a more complex definition: "a structure of interconnected greenways (trails, stream corridors) and green hubs (forests, farms, parks) located throughout a region to protect wildlife diversity, ecological processes, air and water quality and recreation opportunities. In "Perspectives on the Use of Green Infrastructure for Stormwater Management in Cleveland and Milwaukee", Keeley et al (2012) analyzes the challenges of integrating both grey and green infrastructure using the two cities as case studies. Green infrastructure was identified as having two major roles: stormwater management and urban revitalization. Challenges were measured across the categories of financial, administrative and political, and technical. The study concluded that financial issues were the strongest indicator of green infrastructure installation.

The Warren et al (2009) examined the benefits of green infrastructure in great depth. The research states that green infrastructure has been shown to protect and/or improve water quality mainly through increased infiltration. Incorporation of green infrastructure in a watershed-based plan could significantly decrease stormwater runoff volume and water pollution. Green infrastructure can potentially lower maintenance costs in the long-term mainly due to the reduction in stormwater flowing through 'structural controls' (Warren et al, 2009). The study also discussed the prospect of green infrastructure planning and implementation at the state, regional and local levels. In evaluating the most successful GI principles, Warren et al (2009) point out that green infrastructure systems operate much more efficiently when whole rather than fragmented. These systems are typically composed of larger and smaller 'hubs' or areas of open space with links, which can be greenways or stream corridors (Warren et al, 2009). The literature supports the idea that protection of large undeveloped tracts of land, particularly surrounding stream areas, is a significant component of protecting water quality and infiltration (Warren et al., 2009). This is referred to as 'large tract conservation' and should be considered an important component of watershed-based stormwater control plans. 
A study conducted by Nancy Carlin, was very valuable to the research conducted for this project. She explored flash flooding risk in this region in Wisconsin (Carlin, 2009). The author stated that most flash flooding occurs when too much water accumulated on saturated ground by heavy rains and the water has nowhere else to go. Flash flooding can take minutes or hours to develop and transpire with little warning, making flash flooding extremely dangerous (Carlin, 2009). Carlin's study was focused on evaluating areas susceptible to repeat flash flooding in La Crosse County, Wisconsin. To define areas with highest risk factors (i.e. most likely to flood, soil type, land use, slope, and stream proximity etc.) were used in three levels: 1) most favorable or best locations to least likely to experience flash flooding, 2) moderate conditions, and 3) the least favorable or areas most likely to experience flash flooding. The study also looked at infrastructure damage in comparison to the flash flood area results. The results of the study found that most infrastructure sites were not in the flash flood risk area. This is most likely due to the fact that buildings were not placed in this area due to being located in floodplains or having a history of flooding. This approach was used in this study to build the methodology of defining areas susceptible to flash flooding in Philadelphia.

\section{Method}

\section{Data Acquisition}

This study is based on four different sorts of data. These are soil types, land use, streams, and elevation. Soil was obtained from the Natural Resources Conservation Service (NRCS). Land use, streams, and contours were accessible through the Pennsylvania Spatial Data Access (PASDA).

\section{Data Preparation}

A ranking process to rate the susceptibility of areas to flash flooding is used in this study. This process is based on the Carlin (2009) mentioned previously. The process can be presented as follows:

- 1: Least likely to experience flash flooding

- 2: Moderately likely to experience flash flooding

-3: Most likely to experience flash flooding

All original data was in vector format and through our analysis was converted to raster by using 'topo to raster' and 'polygon to raster' tool. A cell size of 50 feet was used for the output raster data that gave the clearest and most aesthetically pleasing result. The soil layer required slightly more preparation prior to the analysis. Tabular data had to be joined to the shapefile in order for it to contain the necessary attribute information. This data was used as the field containing soil drainage information.

\section{Soil Layer}

The soil types were classified into three groups based on soil drainage characteristics. The folowing tables show the soil types contained in each class (Tables $1-3$ ). 
Table 1. Class 1: Well drained soils used for reclassification purposes

\begin{tabular}{ll}
\hline \multicolumn{2}{c}{ CLASS 1: Well Drained } \\
\hline Gravel pit & Excessively drained \\
Chester silt loam & Well drained \\
Manor loam & Well drained \\
Manor extremely loam & Well drained \\
Duncannon silt loam & Well drained \\
Edgement channery loam & Well drained \\
Alton gravelly loam & Well drained \\
Source: NRCS & \\
\hline
\end{tabular}

Table 2. Class 2: Moderately drained soils used for reclassification purposes

\begin{tabular}{ll}
\hline \multicolumn{2}{c}{ CLASS 2: Moderately Drained } \\
\hline Codorus silt loam & Moderately well drained \\
Glenville silt loam & Moderately well drained \\
Lawrenceville silt loam & Moderately well drained \\
Rowland silt loam & Moderately well drained \\
Urbana silt loam & Moderately well drained \\
Alluvial Land & Somewhat poorly drained \\
Chalfant silt loam & Somewhat poorly drained \\
Bowmansville silt loam & Somewhat poorly drained \\
Source: NRCS & \\
\hline
\end{tabular}

Table 3. Class 3: Poorly drained soils used for reclassification purposes

\begin{tabular}{ll}
\hline \multicolumn{1}{c}{ CLASS 2: Poorly Drained } \\
\hline Hatboro silt loam & Poorly drained \\
Doylestown silt loam & Poorly drained \\
Marsh & Very poorly Drained \\
Source: NRCS & \\
\hline
\end{tabular}

The soils accounted in the first class are well and excessively well drained. The second class soils are moderately well and somewhat poorly drained. The poorly and very poorly drained soils are mentioned in the third class. The soil shapefile was converted to raster using polygon and then reclassified using the values specified above. The contours, the DEM, and the slope maps of the the area are presented in Figure 2.

\section{Land Use Layer}

The land use types were classified in three levels based on runoff potential: 1) Low runoff, 2) Moderate Runoff, and 3) High Runoff. The runoff potential for each land use category is presented in Table 4 for Philadelphia county landuse. 
Table 4. Class 3: Poorly drained soils used for reclassification purposes

\begin{tabular}{cccc}
\hline & \multicolumn{3}{c}{ Philadelphia County Landuse } \\
\cline { 2 - 4 } Civic/Institution & Runoff Potential & Acres & \% of County \\
Commercial & High & 4390 & 4.8 \\
Culture/Recreation & High & 4370 & 4.8 \\
Industrial & Moderate & 3251 & 3.6 \\
Park/Open Space & High & 10773 & 11.8 \\
Residential & Low & 8842 & 9.7 \\
Transportation & High & 25922 & 28.3 \\
Vacant or Other & Moderate & 23838 & 26.1 \\
Water & Low & 4869 & 5.3 \\
County Total & Restricted & 5248 & 5.7 \\
Source: PASDA, 2013 & - & 91503 & 100 \\
\hline
\end{tabular}

Park/open space and vacant land uses were given a low runoff potential, culture/recreation and transportation areas were given a moderate runoff potential and civic/institution, commercial, industrial and residential areas were given a high runoff potential. Herein the land use was converted to a raster file using polygon to raster and reclassified using the above classification. Reclassification of land use can be seen in Figure 3.

\section{Elevation Layer}

The elevation layer required several more steps before reclassification. This process is displayed in Figure 2. First, a topo to raster conversion was done to get a digital elevation model (DEM) for Philadelphia. Next the slope tool was used. The slope was classified into three groups using natural breaks. Three elevation rankings were determined according to the slope percentage. Areas that have less than 8 percent slope were represented with the class \# 1. The land in this class are most favorable areas or least likely to experience flash flooding. Areas that have slope of 8-27 percent were represented with the class \#2. Such areas are moderately favorable or areas moderately likely to experience flash flooding. Areas with the slope greater than 27 percent were accounted in the third class. According to the above mentioned consideration, the lands were reclassified and the reclassification based on land elevation were mapped as seen in Figure 2.

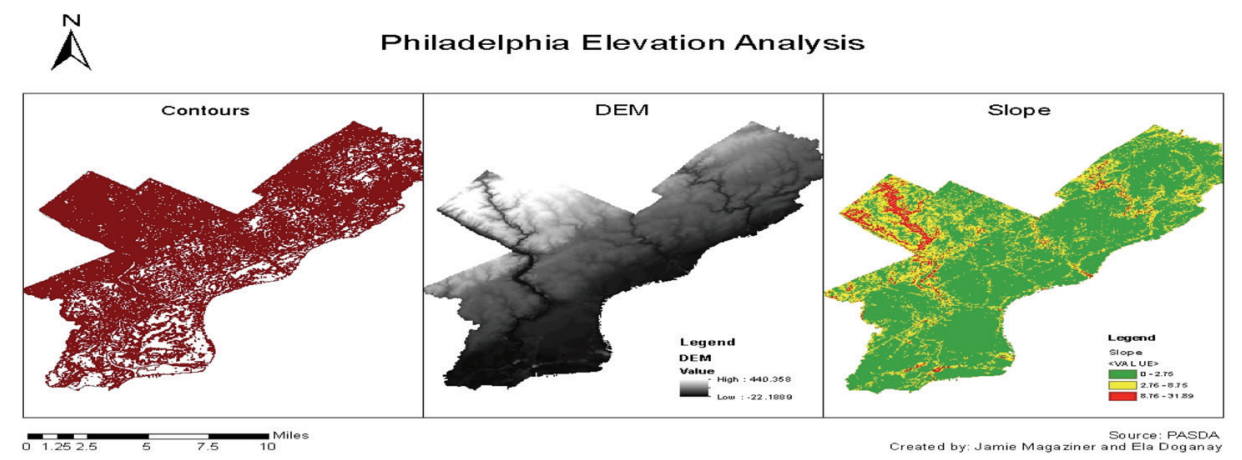

Figure 2. Conversion of Contours Data to Slope: a) contours, b) DEM, and c) slope 


\section{Stream Layer}

Because sites close to streams have the highest flooding risk, a multiple ring buffer analysis was made for each 100, 200, and 300 feet elevation. This polygon buffer output was then converted to a raster via polygon to raster based on the weight field. The areas between 300 and 200 feet altitude were evaluated in the first class. Such lands are the most favorable areas or the least likely to experience flash flooding. The areas between 200 and 100 feet altidute were accounted in the second class. Such areas are moderately likely to experience flash flooding. The areas have the altidute less than 100 feet (i.e. closest to a stream) were accepted as third class lands. These lands are the least favorable and the most likely to experience flash flooding. Next, the raster was reclassified based on the above classification as mapped in the Figure 3.

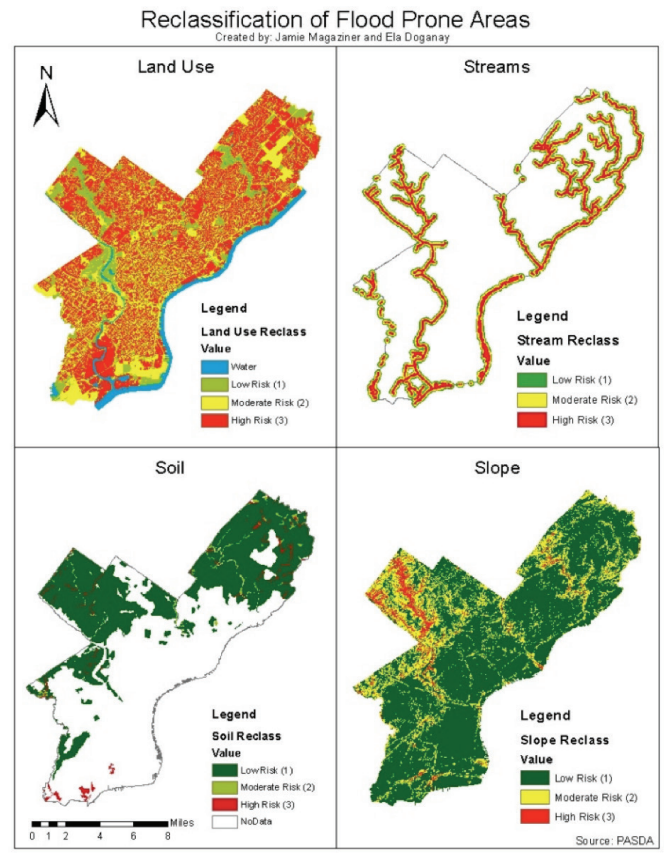

Figure 3. Reclassification of Flood Prone Areas: a) land use, b) streams, c) soil, d) slope

\section{Results}

\section{Analysis and Results}

Using the reclassified streams, soil, land use, and slope outputs, a weighted overlay was determined to find the areas most susceptible to flash flooding in Philadelphia. The entire methodology and analysis is resulted as a flood risk mapp which is presented in Figure 4. A similar symbology was used throughout this analysis to remain consistent. Red areas represent areas highly likely to experience flash flooding, yellow represent areas moderately likely to experience flash flooding, and finally, green represents areas least likely to experience flash flooding. One can see from the map that green stormwater projects are largely focused within the combined sewer area. This is important for decision making on the which area has the highest likelihood to reduce combined sewer overflows and meet the EPA mandate for the city. 
It can also be seen that the areas susceptible to flash flooding are outside of the combined sewer system. This situation has several reasons: First, since these streams are buried in ground into the pipes and culverts, when looking within the combined sewer system the surface of the streams is invisible. On the other hand, since stream data was one of the components of the reclassification and overlay, any flash flood areas is not be expected on a stream free zone. Additionally, the used soil data had a 'blank' value for a large area of Philadelphia, particularly within the combined sewer area. This may be because of high impervious cover but it is yet to be determined. This is also contributed to the resulted locations.

Based on concentrated areas of high risk, we focused on three areas to recommend further evaluation. These can be seen in Figure 4. and Figure 5. Policy recommendations for these areas are in the relevant section below. The first focus area is entirely outside of the combined sewer system in an area with a high slope. This location contains the highest concentration of high risk area in the city. There are only 3 green stormwater projects in this severe area. The following two focused areas are bordering the combined sewer system with some areas overlapping it. These two 'bordering' areas both only contain one project in or in close proximity to them. This lack of projects may have an impact on how floodwaters interact with these areas and enter the combined sewer system. Further discussion of these areas is in the Policy Recommendations section.

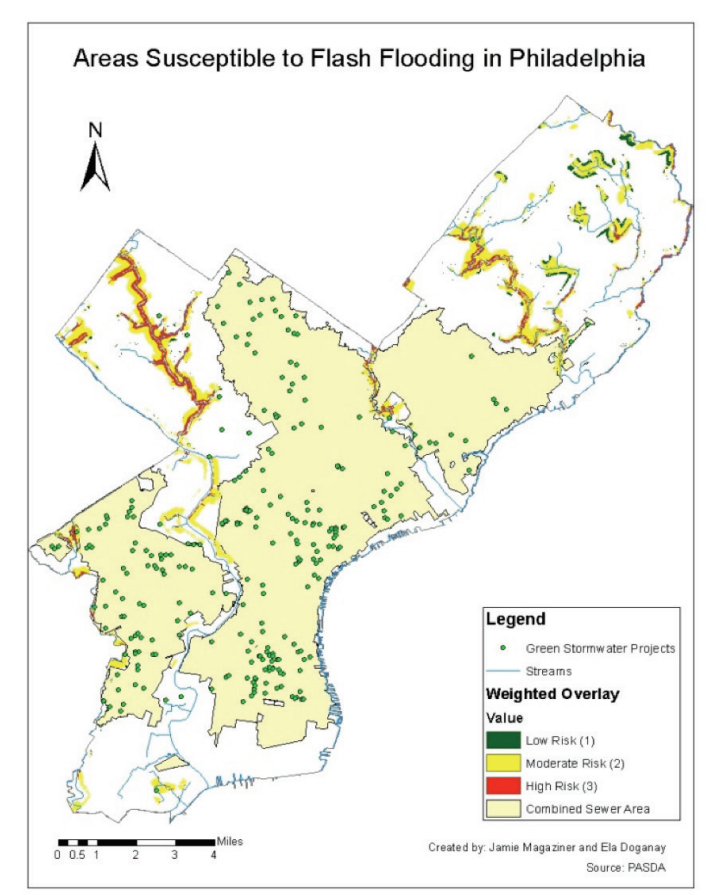

Figure 4. Areas Susceptible to Flash Flooding in Philadelphia 


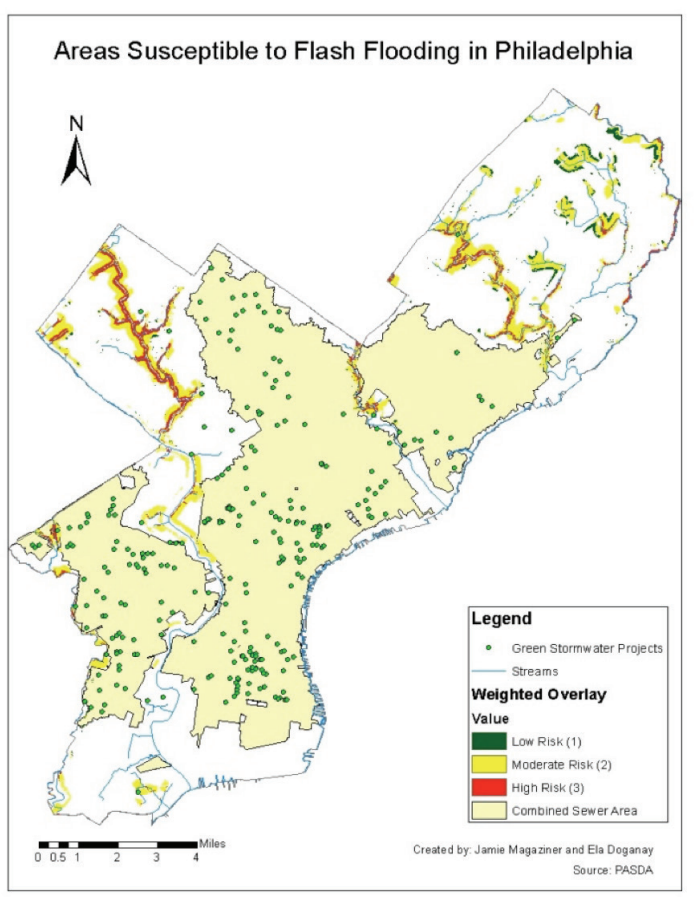

Figure 5. Areas Susceptible to Flash Flooding in Philadelphia
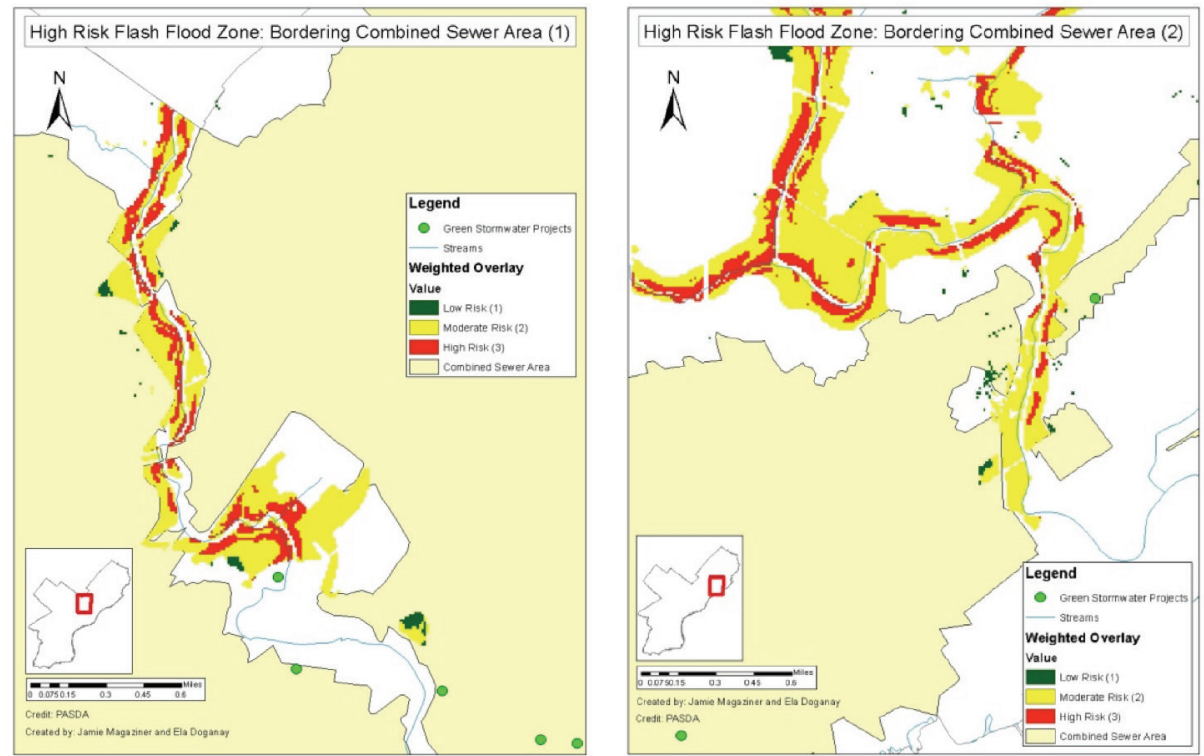

Figure 6. Areas Susceptible to Flash Flooding in Philadelphia

\section{Issues, Solutions and Future Tasks}

There was one significant issue with data for this project. The green stormwater project data, obtained from PASDA, was updated and available on January 2nd, 2013. However, on the Green City, Clean Waters website, the numbers of projects is significantly higher than the number of proj- 
ect data used in the analysis. The webpage is recorded as being updated on March 28th, 2014; thus, the used data does not reflect the current situation. Tables 5 and 6 display the differences in the numerical information for green stormwater projects in Philadelphia.

Table 5. Green Stormwater Data Used in Analysis

\begin{tabular}{cc}
\hline Project Type & Number of Projects \\
\hline Stormwater Tree Trenches & 138 \\
Stormwater Planters & 13 \\
Stormwater Bumpouts & 33 \\
Rain Gardens & 37 \\
Stormwater Basins & 3 \\
Infiltration/Storage Trenches & 12 \\
Porous Paving & 27 \\
Swales & 2 \\
Stormwater Wetlands & 2 \\
Cistern or Rain Barrel & 0 \\
Downspout Planters & 0 \\
Other & 10 \\
Total & 277 \\
PWD Data updated 1/2/13 & \\
\hline
\end{tabular}

Table 6. Green Stormwater Numbers on Philly Watersheds website

\begin{tabular}{cc}
\hline Project Type & Number of Projects \\
\hline Stormwater Tree Trenches & 342 \\
Stormwater Planters & 38 \\
Stormwater Bumpouts & 45 \\
Rain Gardens & 101 \\
Stormwater Basins & 5 \\
Infiltration/Storage Trenches & 112 \\
Porous Paving & 37 \\
Swales & 23 \\
Stormwater Wetlands & 2 \\
Cistern or Rain Barrel & 1 \\
Downspout Planters & 33 \\
Other & 17 \\
Total & 756 \\
PWD Data updated 1/2/13 & \\
\hline
\end{tabular}

It can be seenfrom the tables that the updated information contains a total of 756 projects as compared to the 277 projects recorded in the data used in the analysis. The newly updated information is not yet available as downloadable data. It may due to the fact that our results may not be accurate in revealing trends in the locations of green stormwater projects. When simply looking at the maps in comparison one to another, they do seem to avoid the edges of the combined sewer area. These are the areas that we suggest need projects due to flood risk, because our results may still be relatively accurate. We suggest that this analysis should be redone at the time of updated data availability to ensure this accuracy. It is important to note that many of these projects are in design and in 
construction. Due to the short time period between the PASDA data used in this analysis and the Big Green Map numbers, it is likely that many of these are in design and do not immediately impact the results of this analysis. Figure 7 represents a screenshot from the Philly Watersheds webpage that shows the points representing green stormwater projects.

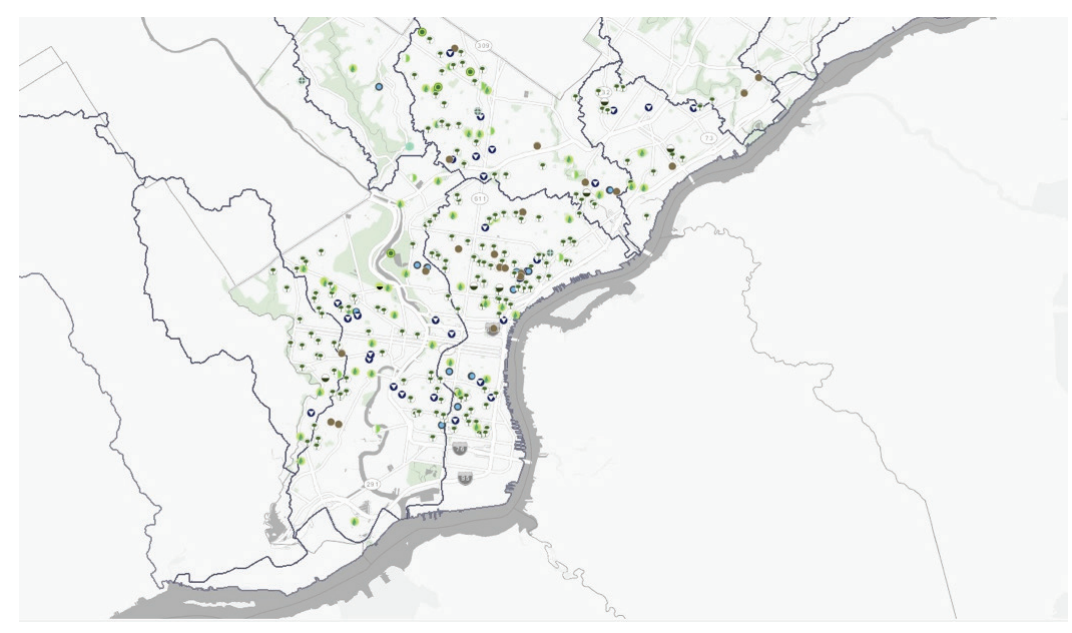

Figure 7. Philly Watersheds: Big Green Map http://phillywatersheds.org/biggreenmap

There are also other opportunities for further research involving this project. Further analysis of both the entire city and the focus areas we determined in our study could be done using the Hydrology tools in ArcGIS. These tools could help to determine flow direction going in and out of the sewer system. This would clarify areas of highest need if flow was entering the combined sewer area in areas of high flood or flash flood risk. Another area of further analysis would be to evaluate the areas suggested in the Policy Recommendations section of this paper. Characteristics of the areas such as land use, impervious cover, and areas available for green stormwater projects could help to assess which locations are the most suitable for projects as well as what types of projects would be the most appropriate.

\section{Policy Recommendations}

These policy recommendations refer to Figures 5 and 6 in the "Analysis and Results" section of this paper. As discussed in the section, green stormwater projects are consistently distributed throughout the combined sewer area, but are lacking on its borders and within flash flood prone areas. This areas could significantly impact flow into the combined sewer system, thus impacting combined sewer overflows, therefore it is recommended that several projects should be focused in the areas specified in Figures 5 and 6. These projects should be located in the moderate to high risk zones where they can have the most impact. As stated in the above section of this paper, further analysis of these areas and their characteristics can help to narrow down what types of green stormwater projects would be most appropriate for each location. We recommend that further analysis is conducted prior to any action being taken in project implementation. Characteristics of recommendation areas need to be known in order to take further steps. 


\section{Discussion and Conclusion}

Flash flood risk is a high concern for the focused areas determined by this study. The results imply that green stormwater management projects are consistently distributed across the combined sewer area but are not typically present around its boundaries which are aligned with Philadelphia's rivers and flash flood prone areas. Flash flood prone areas are mainly at the outside of the combined sewer area but likely have an impact on how flooding occurs near and within the CSS. The methodology used in this study has the potential to be replicated and expanded upon for further research. It is clear that green stormwater infrastructure projects are well distributed across the combined sewer area. The results of this analysis conclude that there is room for further expansion of projects in areas bordering the CSS in zones of high flash flood risk. Further analysis of characteristics of these areas is necessary in order to determine the types of projects most appropriate. Due to the seriousness of combined sewer overflows, these recommendations should not be taken lightly as they have high potential of reducing CSOs. Further research could strengthen this study and reinforce its recommendations for Philadelphia.

\section{Acknowledgement}

Some parts of the article was presented as poster presentation at the meeting of the Philadelphia Metropolitan Area Section of the American Water Resources Association (AWRA-PMAS) . 


\section{References}

Bartosova, A. ,Clark, D., Novotny,V.\& Taylor, K. (2000). Using GIS to Evaluate the Effects of Flood Risk on Residential Property Values. Retrieved May 12014 from http://epublications. marquette.edu/cgi/viewcontent.cgi?article $=1132 \&$ context $=$ econ_fac

Carlin, N. (2009). Spatial Analysis Using GIS to Evaluate Areas Susceptible to Flash Flooding in La Crosse County, Wisconsin. Retrieved April 292014 from http://www.gis.smumn.edu/ GradProjects/CarlinN.pdf

EPA. (2013). Case Studies Analyzing the Economic Benefits of Low Impact Development Green Infrastructure Programs. Retrieved April 252014 from http://water.epa.gov/infrastructure/ greeninfrastructure/gi_costbenefits.cfm

EPA. (2013). Green and Gray Infrastructure Research. Retrieved April 202014 from http://www. epa.gov/nrmrl/wswrd/wq/stormwater/green.html

Keeley, M., Koburger, A., Dolowitz, D. P., Medaris, D., Nickel, D., \& Shuster, W. (2013). Perspectives on the Use of Green Infrastructure for Stormwater Management in Cleveland and Milwaukee. Environmental Management, 51, 1093-1198.

Philadelphia Water Department (PWD). (2011). Green City Clean Waters: The City of Philadelphia's Program for Combined Sewer Overflow Control. Retrieved April 182014 from http://www.phillywatersheds.org/what_were_doing/documents_and_data/cso_long_ term_control_plan

PWD. (2012). Green Cities, Clean Waters. Retrieved April 182014 from http://www. phillywatersheds.org/what_were_doing/documents_and_data/cso_long_term_control_plan

PWD. (2014). Mandates. Retrieved April 202014 from http://phillywatersheds.org/watershed_ issues/mandates

Warren, M. P., Younos, T. \& Randolph, J. (2009). Implementing Watershed-Based Green Infrastructure for Stormwater Management: Case Study in Blacksburg, Virginia. Retrieved April 20, 2014, from http://vwrrc.vt.edu/special_reports.html 


\section{Extended Turkish Abstract (Genişletilmiş Uzun Türkçe Özet) \\ Filedalfiya'da Ani Taşkınlar ve Çevreci Yağmur Suyu Altyapıları: Geliştirilmesi Gereken Bölgeler}

En tehlikeli afetlerden olan taşkın Amerika Birleşik Devletlerin'de en çok yaşanan doğal afetlerden biridir. Her taşkın aynı şekilde gerçekleşmez. Taşkınların bazıları birkaç gün sürerken, çok kısa sürede yaşanan ani taşkınlar da vardır. Ani taşkınlar, taşkın riski taşımayan bölgelerde dahi aşırı yağmur suyunun doygunluğa ulaşmış toprak üstünde birikip yayılmasından dolayı kısa sürede meydana gelebilir. Artan kentleşme ile birlikte şehirlerde geçirimsiz yüzeylerin çoğalması, şehir taşkınlarının artmasındaki en önemli etkenlerden biri haline gelmiştir (Bartosova et al, 2000). Ani taşkınların birçoğu yoğun yağış durumunda, bir kaç dakika ya da bir kaç saat içinde meydana gelir ve hasar verme potansiyeli yüksektir. Bundan dolayı, bu çalışmada birçok nehire sahip ve yoğun kentleşme görülen Filedelfiya şehrinde ani taşkın riski taşıyan bölgelerin belirlenmesi amaçlanmıştır.

Filedelfiya taşkın ve yağmur suyu kontrolünde çevreci yağmur suyu toplama altyapıları kullanımında öncü bir şehirdir. Filedelfiya, Amerika Birleşik Devletleri’ndeki diğer pek çok eski şehir gibi birleşik kanalizasyon sistemine (BKS) sahiptir. Yağmur yağmadığı zamanlarda, sistem sadece atıksu taşımakta, yağmur yağdığı durumlarda, aşırı yağmur suyu kanalizasyon sisteminde toplanmakta, sistemin kapasitesini aşması durumunda ise kanalizasyon taşkınını önlemek amacıyla atıksu, yağmur suyu ile birlikte akıp nehre dökülmektedir. Bu durum kanalizasyon kapasitesinin aşılması (KKA) durumu olarak ifade edilmektedir. Nehir ekolojisini, sucul yaşamı ve su kalitesini olumsuz etkilemesinden dolayı Filedelfiya Çevre Ajansı'nın yürütmekle sorumlu olduğu Temiz Su Kanunu'nu (TSK) ihlal edilmektedir. Bu Kanun gereği KKA durumunun önlenmesi zorunludur (PWD, 2014). Bundan dolayı Fildelfiya'da uzun vadede yağmur suyu kontrolünü ve su kalitesini korumak amaciyla Yeşil Şehir-Temiz Su Programı hazırlanmıştır. Bu programla, hem programın amacını gerçekleştirmek hem de KKA oluşumunu önlemek için çevreci yağmur suyu altyapıları uygulamasına başlanmıştır. Bu makale çalışması kapsamında, Filedelfiya'da ani taşkın riski taşıyan bölgelerin, birleşik kanalizasyon sistemine mesafeleri ve bu bölgelerde çevreci yağmur suyu altyapılarının mevcudiyeti belirlenmeye çalışılmıştır. Bu amaç doğrultusunda, Filedelfiya'daki ani taşkın riski olan bölgeleri belirlemek amacıyla Coğrafik Bilgi Sistemi (CBS)' ne dayalı analitik bir model oluşturulmuştur. Analiz sonucunda riskli olduğu belirlenen bölgelerde mevcut bulunan kanalizasyon şebekelerinin konumu ve bu bölgelerde çevreci yağmursuyu toplama yapılarının olup olmadığı ve bu sistemlerin birbiriyle olan etkileşimleri incelenmiştir.

Bu çalışma kapsamında şu sorulara cevap aranmıştır:

- Filedelfiya'da ani taşkın riski taşıyan bölgeler

- Bu bölgelerin, birleşik kanalizasyon sistemine sahip alanların içerisinde kalıp kalmadığı

- Çevreci yağmur suyu altyapılarının bu bölgelerde mevcudiyeti.

Bu çalışmada CBS programının Weighted Overlay özelliği kullanılmıştır. Bu özelliğin çalışma prensibi, model için kullanılan verileri, özelliklerine göre kendi içinde gruplandırıp belirlenen kritere dayanarak veriye bir değer atamak şeklindedir. CBS modelinde, toprak cinsi, arazi kullanımı, nehre yakınlık ve sayısal yükseklik verileri olmak üzere 4 farklı veri kullanılmıştır. Toprak verisi Doğal Kaynakları Koruma Servisi'nden (Natural Resources Conservation Service-NRCS), arazi kullanımı, nehre yakınlık ve sayısal yükseklik verileri ise Pensilvanya Mekânsal Veri Erisimi’nden (Pennsylvania Spatial Data Access (PASDA) elde edilmiştir. Bir bölgenin ani taşkın riski potansiyelini belirlemek için bir puanlama yöntemi kullanılmıştır. 
- 1 puan: Taşkın riski olma ihtimali en az

- 2 puan: Taşkin riski olma ihtimali orta derece

- 3 puan: Taşkin riski olma ihtimali yüksek

Her veri, verinin taşkın riskini etkileme değerine göre gruplandırılarak puanlanmıştır. Toprak yapısı verisi drenaj kalitesine göre üç gruba ayrılmıştır: iyi drene, orta drene ve kötü drene toprak olmak üzere. İyi drene toprağın su geçirgenliği yüksek olduğundan çok miktarda su hızlı bir şekilde toprağa sızacak ve akışa geçen su miktarı daha az olacaktrr. Bu sebeple puanlama yapıllırken iyi drene toprağa taşkın riski çok düşü̈k olduğu için 1 puan, orta drene toprağa 2 puan ve kötü drene toprağa ise, nispeten daha az su sızacağı için ani taşkın riski yüksek olduğu öngörülerek 3 puan atanmıştır. Endüstriyel alanlar, yerleşim yerleri, parklar, tarihi mekânlar, şehir merkezleri, yollar ve boş alanlardaki toprağın kaplı olduğu malzemeye göre yağmur suyu akışının değişeceği gerçeğinden hareketle değerlendirme yapılmıştır. Örneğin endüstriyel bölgelerde toprak üstünün betonla kaplı olduğu alanların miktarı çok olacağından akışa geçen su miktarının da aşııı olacağı öngörüsünden hareket edilmiştir. Park ve mesire yerlerinde genel olarak toprak yüzeyi bitkilerle örtülmüş veya çıllak olacağından dolayı yağmur suyunun büyük oranda toprağa sızacağı ve daha az akış olacağı ön kabulüyle hareket edilmişstir. Akışa geçen su miktarı az, akışa geçen su miktarı orta ve akışa geçen su miktarı çok olarak veriler üç grupta toplanmış ve her gruba sırasıyla 1,2 ve 3 puanları atanmıştır. Nehre yakınlık riski için nehre 100, 200 ve 300 fit uzaklık dikkate alınarak 3 ayrı tampon bölge oluşturulmuş̧ur. Nehre 100 fit uzaklı̆ındaki bölge, nehrin taşması durumunda, nehre yakın olmasından dolayı daha çok risk taşımaktadır. Bu sebeple 100 fit uzakliktaki bölgeye 1, 200 fit uzaklıktaki bölgeye 2 ve 300 fit uzaklıktaki bölgeye 3 puan verilmiştir. Son olarak sayısal yükseklik verisi kullanılarak eğimli bölgeler belirlenmişstir. Eğim verileri, $\%$ ' den düşük eğim, $\% 8$ ile 27 arası eğim ve $\% 27$ 'den yüksek olmak üzere üç gruba ayrılmıştrr. Eğimin yüksek olduğu yerlerde yağmur suyu akış hızının da yüksek olacağı ve bu sebeple suyun toprağa sızma miktarının düşük olacağı göz önünde bulundurularak $\% 8$ 'den düşük olan gruba 1, eğimi $\% 8$ ile yüzde 27 arasında olan gruba 2 ve eğimi yüzde 27 'den yüksek olan gruba 3 puan verilmiştir.

CBS programında Weighted Overlay özelliği ile veriler kendi içinde sıııflandırlıp ani taşkın riski potansiyellerine göre derecelendirilip analizi yapıılmıştır. Analiz sonucu elde edilen haritalarda Filedelfiya şehrinde ani taşkın olma ihtimali yüksek olan bölgeler öngörülmüştür. Harita üzerinde riskli bölgelerin birleşik kanalizasyon sistemine yakınlığı ve o bölgelerde çevreci yağmur suyu toplama altyapılarııın mevcudiyeti de değerlendirilmiştir. 